\title{
Pathology and biomechanics of the human achilles tendon
}

\begin{abstract}
Biomechanical engineering has achieved much progress in an attempt to improve and recover impaired functions of tissues and organs. Although many studies have been done, progress for biomechanical-engineered Achill tendon has been slow due to their complex structures and mechanical properties. In this review, the Achill tendon anatomical structure, mechanical properties, and risk factors of rupture have been discussed. This is a considerably huge amount work that needs to be carried out; as such, future direction in tendon biomechanical engineering is proposed in hope that this review will give information on future tendon biomechanical engineering.
\end{abstract}

Keywords: Achilles tendon, Mechanical properties, Risk factors
Volume 9 Issue 2 - 2017

\author{
Mozhgan Faraji Aylar,' Faramarz Firouzi, ${ }^{2}$ \\ Hamidreza Kubravi ${ }^{2}$ \\ 'Faculty of engineering, Electrical engineering department, Imam \\ Reza International University, Iran \\ ${ }^{2}$ Faculty of engineering, Department of biomedical engineering, \\ Islamic Azad University, Iran
}

Correspondence: Mozhgan Faraji Aylar, MS, Electrical engineering department, Imam Reza International University, Asrar St., Daneshgah Ave., Mashhad, Iran, Emailm.faraji@imamreza.ac.ir

Received: February 20, 2017| Published: October 20, 2017

\section{Introduction}

The tendinous portions of the gastrocnemius and soleus muscles merge to form the Achilles tendon. ${ }^{1}$ Achilles tendinopathy, including tendon rupture, occur at a rate of about 250,000 per year in the US alone. ${ }^{2,3}$ The incidences of Achilles tendon ruptures have significantly increased over the last 20 years, ${ }^{2,4}$ achieving, within the tendon disease, an incidence between 6 and $18 \% .^{5-7}$ The Achilles tendon rupture etiology remains poorly known $\mathrm{n}^{8,9}$ and it is essentially based on two main theories: the degenerative theory and the mechanical theory.

In humans, the Achilles tendon is the thickest and strongest tendon that sustains some of the largest tensile loads in the body. ${ }^{10}$ Dysfunction and injuries are commonly seen in the Achilles tendon. The fibrous matrix of tendons mainly consists of collagen and a small amount of elastin, which are produced and maintained by tenoblasts and tenocytes. ${ }^{11}$ Tendon consists primarily of collagen $(70-80 \%$ of the tissue's dry weight) and less than $5 \%$ tenocytes and tendoblasts. ${ }^{12}$ These insoluble elements are embedded within a hydrated environment containing ground substance of proteoglycans, glycosaminoglycan (GAG) and some other small molecules. ${ }^{13}$

The mechanism of tendinopathy and rupture is complex and thought to be influenced by tendon geometry, material-strength, sex, disease and genetics. Achilles tendon rupture is typically reported to occur at 2-6 $\mathrm{cm}$ above the insertion to the calcaneus bone, in a region that is hypovascular. ${ }^{14}$ It is not understood why this region receives poor blood supply and is prone o rupture.

Research on Achilles tendon has been going on for some time, with the hope of overcoming the present problems. Usually, mechanical and structural information about Achilles tendon are necessary to facilitate studies in biomechanical, tissue engineering, surgical and rehabilitation fields.

\section{Methods}

In this review, we try to find mechanical properties in vivo and in vitro because of calculating the human Achill tendon's properties passively and actively. In addition, identifying of structure and risk factors of Achill tendon can provide appropriate information to scientists.

\section{Results}

\section{Mechanical properties}

The functional and mechanical behavior of human skeletal muscle are in many ways unknown during natural and artificial locomotion. To gain more insight into these questions a method was developed to record directly in vivo and in vitro forces from the human Achilles tendon. The Table 1 shows the mechanical properties of the Achill tendon.

\section{Structure of fibrous matrix}

The Table 2 shows the biomechanical constituents of the Achill tendon. The recent study ${ }^{15}$ showed that while the majority of the Achilles tendon is supplied by the posterior tibial artery from its medial edge, the peroneal artery provides supply to the middle section of the tendon laterally. The midsection of the Achilles tendon was found to be hypovascular in all cases of the study.

\section{Risk factors}

The Achilles tendon is the most frequently ruptured tendon. The Table 3 shows the risk factors of the Achilles tendon rupture. The ruptured Achilles tendons show various forms of degenerative tendinopathy. It is not known why there are differences in types and amounts of degeneration between individual tendons, although there is evidence suggesting that decreased arterial blood flow, resulting local hypoxia and impaired nutrition and metabolic activity are the key factors. A sedentary lifestyle has been proposed as the main reason for poor circulation in the tendon.

\section{Discussion}

This research investigated the properties of human Achilles tendon materially, mechanically, anatomically, and pathologically. The human Achilles tendon is the thickest and strongest tendon among all of human's tendons.${ }^{10}$ The incidence of total Achilles tendon rupture has increased during the past decade. The rise is more prominent among men and in the context of sports-related injuries. Majority of ruptures occurs in recreational involved in sports requiring bursts of jumping, pivoting and running (Table 3). Lack of a universal, consistent protocol 
for passive and active evaluation of Achilles tendon has prevented any and compare the results and seek prognostic factors related to the direct comparison of results. This paper makes it possible to analyze results.

Table I Summary of structural and mechanical properties of human Achilles tendon

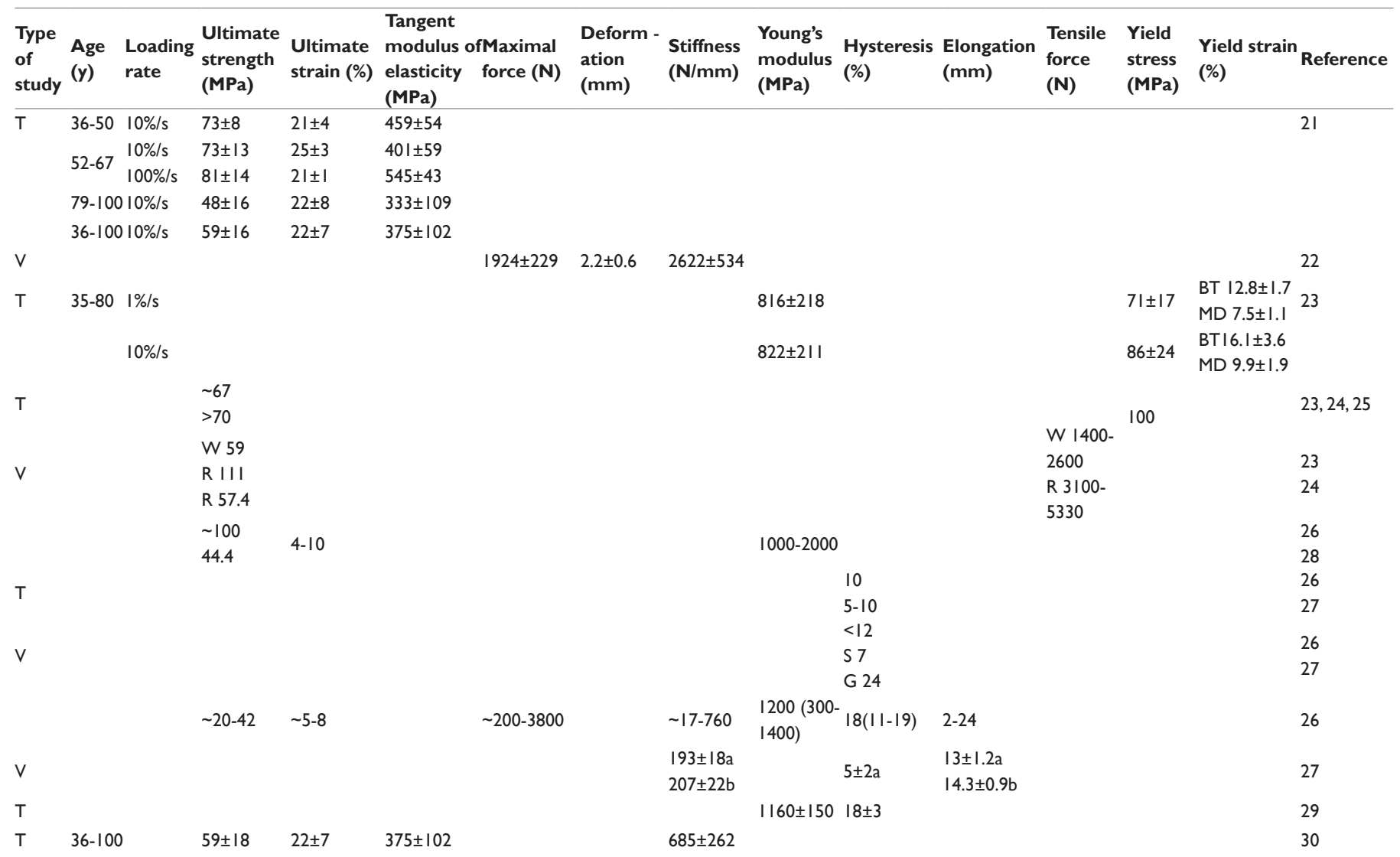

Values are in second: mean \pm SD. Abbreviation: $R$ (running), W (walking), $V$ (in vivo), $T$ (in vitro), BT (bone-tendon), MD (midsubstance), $S$ (attach to soleus), $G$ (lateral and medial Gastrocnemius), $10 \%$ and $80 \%$ of maximum voluntary contraction (MVC) forces at fast (a) and slow (b) loading rates.

Table 2 The biomechanical constituents of Achilles tendon

\begin{tabular}{|c|c|c|c|}
\hline Contents of fibrous matrix & Value (\%) & Explanation & Reference \\
\hline Collagen I & $95 \%$ & All of collagens $70 \%$ (dry weight) & 16,17 \\
\hline Collagen II & & & 17 \\
\hline Collagen III & & & $16-18$ \\
\hline Collagen IV & & & 17 \\
\hline Collagen V & & & 17,19 \\
\hline Collagen VI & & & 17 \\
\hline Elastin & $\mathrm{I}-2 \%$ (dry weight) & $\begin{array}{l}\text { *Bearing of } 200 \% \text { strain before failure } \\
\text { *Produced and maintained by tenoblasts and tenocytes }\end{array}$ & $16-18,20$ \\
\hline Blood supply Values are in percent. & & $\begin{array}{l}\text { Posterior tibial artery } \\
\text { Peroneal artery }\end{array}$ & 15 \\
\hline
\end{tabular}

Table 3 Summary of Achilles tendon rupture (ATR) risk factors

\begin{tabular}{|c|c|c|c|}
\hline Cause & Explanation & Range & Reference \\
\hline Middle-aged & $\begin{array}{l}\text { Decreasing blood flow rate } \\
\text { Increasing stiffness } \\
\text { Decreasing the ability to withstand stress }\end{array}$ & $\begin{array}{l}30-40 y \\
40-50 y\end{array}$ & $\begin{array}{l}31,36,41 \\
40\end{array}$ \\
\hline male & Male relative to female & $\begin{array}{l}1.7: 1-12: 1 \\
2: 1-19: 1 \\
2: 1-12: 1 \\
5: 1\end{array}$ & $\begin{array}{l}31 \\
32 \\
37,38 \\
41\end{array}$ \\
\hline $\begin{array}{l}\text { Serum lipid profile } \\
\text { (hyperlipidemia) }\end{array}$ & $\begin{array}{l}\text { Total cholesterol (TC) } \\
\text { Triglyceride (TG) } \\
\text { LDL-C } \\
\text { VLDL-C }\end{array}$ & & 31,33 \\
\hline
\end{tabular}


Table Continued.

\begin{tabular}{|c|c|c|c|}
\hline Cause & Explanation & Range & Reference \\
\hline O blood group & & & $31,33,34$ \\
\hline $\begin{array}{l}\text { Inflammatory } \\
\text { conditions }\end{array}$ & & & $31,36,37$ \\
\hline $\begin{array}{l}\text { Autoimmune } \\
\text { disorders }\end{array}$ & & & $31,36,37$ \\
\hline genetic & Collagen abnormalities & & $31,36,37,42$ \\
\hline Infectious diseases & & & $31,36,37$ \\
\hline $\begin{array}{l}\text { Neurological } \\
\text { disorders }\end{array}$ & & & 31,37 \\
\hline drugs & $\begin{array}{l}\text { Injectable steroid (corticosteroid) } \\
\text { Antibiotics (fluoroquinolone) }\end{array}$ & & $31-33,36,37$ \\
\hline $\begin{array}{l}\text { Decreased blood } \\
\text { flow rate }\end{array}$ & $\begin{array}{l}\text { With increasing age } \\
\text { Lowest vascularity area at approximately } 2-6 \mathrm{~cm} \text { from the calcaneal } \\
\text { insertion }(80 \% \text { ATR) } \\
\text { Male } \\
\text { Loading conditions }\end{array}$ & & $\begin{array}{l}36,37 \\
32,35,37,38 \\
37 \\
37\end{array}$ \\
\hline Sport activity & $\begin{array}{l}\text { Recreational (75\% compare with competitive } 8-20 \%) \\
\text { Frequent jumps and landings } \\
\text { Great speed variance \& rapid footwork }\end{array}$ & $\begin{array}{l}\text { Gymnastics } \\
\text { Cheerleading } \\
\text { Dance } \\
\text { Soccer } \\
\text { Football } \\
\text { Basketball } \\
\text { Tennis } \\
\text { Long-distance running }\end{array}$ & $32,37,39$ \\
\hline $\begin{array}{l}\text { Degeneration } \\
\text { (degenerative } \\
\text { theory) }\end{array}$ & Increasing of Collagen III and V & & $32,33,37$ \\
\hline $\begin{array}{l}\text { Violent muscular } \\
\text { strain }\end{array}$ & Acute rupture & & 32 \\
\hline Left side & Right-sided dominance and pushing off with the left & & 32,41 \\
\hline $\begin{array}{l}\text { Repetitive overuse } \\
\text { (mechanical theory) }\end{array}$ & Accumulating of micro-trauma & & $32,36,37$ \\
\hline Dehydration & & & 33 \\
\hline Hyperuricemia & & & 33 \\
\hline Ankle equinus & & & 36 \\
\hline Achilles calcification & & & 36 \\
\hline $\begin{array}{l}\text { Abnormal pronation } \\
\text { and mechanics }\end{array}$ & Subtalarhyperpronation & & 36,37 \\
\hline Hyperthermia & During exercise (after 30 minutes) & & 33,37 \\
\hline Tendon geometry & & & 38 \\
\hline Material-strength & & & 38 \\
\hline
\end{tabular}

\section{Conclusion}

This article tries to help the future studies are about the injuries, rehabilitations, pathology, tissue engineering, and bio-mechanical engineering of Achilles tendon.

\section{Acknowledgments}

None.

\section{Conflicts of interest}

None.

\section{References}

1. Maffulli N. Current Concepts Review-Rupture of the Achilles Tendon. The Journal of Bone and Joint Surgery. 2010;81(7):1019-1036.

2. Järvinen TA, Kannus P, Maffulli N, et al. Achilles tendon disorders: etiology and epidemiology. Foot and Ankle Clinics of North America. 2005;10(2):255-266.
3. Pennisi E. Tending tender tendons. Science. 2002;295(5557):1011.

4. Möller A, Åström M, Westlin NE. Increasing incidence of Achilles tendon rupture. Acta Orthopaedica Scandinavica. 1996;67(5):479-481.

5. Rees JD, Wilson AM, Wolman RL. Current concepts in the management of tendon disorders. Rheumatology: (Oxford). 2006;45(5):508-521.

6. Schepsis A, Jones AH, Haas AL. Achilles tendon disorders in athletes. Am J Sports Med. 2002;30(2):287-305.

7. Mazzone M, McCue T. Common conditions of the achilles tendon. American Family Physician. 2002;65(9): 1805-1810.

8. Maffulli N. Rupture of the Achilles tendon. The Journal of bone and joint surgery. American. 1999;81(7):1019-1036.

9. Williams J. Achilles tendon lesions in sport. Sports Medicine. 1986;3(2):114-135.

10. Yang Xin, Pugh Neil D, Coleman Declan P, et al. Are Doppler studies a useful method of assessing neovascularization in human Achilles tendinopathy? A systematic review and suggestions for optimizing machine settings. Journal of Medical Engineering \& Technology. 2010;34(7-8):365-372. 
11. Kannus P. Structure of the tendon connective tissue. Scandinavian Journal of Medicine \& Science in Sports. 2000;10(6):312-320.

12. Wang T, Gardiner BS, Lin Z, et al. Bioreactor Design for Tendon/ Ligament Engineering. Tissue Engineering Part B: Reviews. 2013;19(2):133-146.

13. Hess GP, Cappiello WL, Poole RM, et al. Prevention and Treatment of Overuse Tendon Injuries. Sports Medicine. 1989;8(6):371-384.

14. Theobald P, Benjamin M, Nokes L, et al. Review of the vascularisation of the human Achilles tendon. Injury. 2005;36(11):1267-1272.

15. Chen TM, Rozen WM, Pan WR, et al. The arterial anatomy of the Achilles tendon: Anatomical study and clinical implications. Clin Anat. 2009;22(3):377-385.

16. Bailey AJ, Lapière CM. Effect of an additional peptide extension of the N-terminus of collagen from dermatosparactic calves on the crosslinking of the collagen fibres. Eur J Biochem. 1973;34(1):91-96.

17. Pang X, Wu JP, Allison GT, et al. The three dimensional microstructural network of elastin, collagen and cells in Achilles tendons. J Orthop Res. 2016;35(6):1203-1214.

18. Eriksen HA, Pajala A, Leppilathi J, et al. Increased content of type III collagen at the rupture site of human Achilles tendon. Journal of Orthopaedic Research. 2002;20(6):1352-1357.

19. Mokone GG, Schwellnus MP, Noakes TD, et al. The COL5A1 gene and Achilles tendon pathology. Scandinavian Journal of Medicine \& Science in Sports. 2006;16(1):19-26.

20. Gigante A, Claudio Chillemi, Claudia Bevilacqua, et al. Effects of elastin-derived peptide on Achilles' tendon healing: an experimental study. Journal of Materials Science: Materials in Medicine. 2003;14(8):717-720.

21. Shaw KM, G Lewis. Tensile Properties of Human Achilles Tendon. Biomedical Engineering Conference, IEEE Biloxi MS. 1997;338-341.

22. Kongsgaard M, CH Nielsen, S Hegnsvad, et al. Mechanical properties of the human Achilles tendon, in vivo. Clinical Biomechanics. 2011;26(7):772-777.

23. Wren TA, Yerby SA, Beaupré GS, et al. Mechanical properties of the human Achilles tendon. Clinical Biomechanics. 2001;16(3):245-251.

24. Gu YD, JS Li, MJ Lake, et al. The mechanical response of Achilles tendon during different kinds of sports. Numerical Methods in Engineering. 2008;24(12):2077-2085.

25. Kongsgaard M, Aagaard P, Kjaer M, et al. Structural Achilles tendon properties in athletes subjected to different exercise modes and in Achilles tendon rupture patients. Applied Physiology. 1985;99(5):1965-1971.

26. Maganaris CN, Narici MV, Maffulli N. Biomechanics of the Achilles tendon. Disability \& Rehabilitation. 2008;30(20-22):1542-1547.
27. Peltonen J, Cronin NJ, Stenroth L, et al. Viscoelastic properties of the Achilles tendon in vivo. Springerplus. 2012;2(212).

28. Blanton PL, Biggs NL. Ultimate tensile strength of fetal and adult human tendons. Biomechanics. 1970;3(2):181-184

29. Maganarisa CN, JP Paul. Tensile properties of the in vivo human gastrocnemius tendon. Biomechanics. 2002;35(12):1639-1646.

30. Lewis G, Shaw KM. Tensile properties of human tendo achillis: Effect of donor age and strain rate. Foot and Ankle Surgery. 1997;36(6):435-445.

31. Ozgurtas T, Yildiz C, Serdar M, et al. Is high concentration of serum lipids a risk factor for Achilles tendon rupture? Clinica Chimica Acta. 2003;331(1-2):25-28.

32. Wertz J, M Galli, Borchers JR. Achilles Tendon Rupture: Risk Assessment for Aerial and Ground Athletes. Sports Health. 2013;5(5):407-409.

33. Bisciotti GN, Eirale C, PLello PP. ABO Blood Groups and Achilles Tendon Injury. Achilles Tendon, Čretnik A (Ed.), Creative Commons by 3.0 license. 2010;p.99-114.

34. Maffulli Nicola, Reaper Jacqueline A, Waterston Stuart W, et al. ABO blood groups and achilles tendon rupture in the Grampian Region of Scotland. Clinical Journal of Sport Medicine. 2000;10(4):269-271.

35. Thompson J, B Baravarian. Acute and chronic Achilles tendon ruptures in athletes. Clinics in Podiatric Medicine and Surgery. 2011;28(1):117-135

36. Maffulli N. Current Concepts Review - Rupture of the Achilles Tendon. Journal of Bone and Joint Surgery. 1999;81(7):1019-1036.

37. Hess GW. Achilles Tendon Rupture: A Review of Etiology, Population, Anatomy, Risk Factors, and Injury Prevention. Foot \& Ankle Specialist. 2010;3(1):29-32.

38. Shim VB, Fernandez JW, Gamage PB, et al. Subject-specific finite element analysis to characterize the influence of geometry and material properties in Achilles tendon rupture. Journal of Biomechanics. 2014;47(15):3598-604.

39. Erickson BJ, Cvetanovich GL, Nwachukwu BU, et al. Trends in the Management of Achilles Tendon Ruptures in the United States Medicare Population, 2005-2011. Orthopedic Journal of Sports Medicine. 2014;2(9)

40. Garneti N, Holton C, Shenolikar A. Bilateral Achilles tendon rupture: A case report. Accident and Emergency Nursing. 2005;13(4):220-223.

41. Mezzarobba S, Bortolato S, Giacomazzi A, et al. Percutaneous repair of Achilles tendon ruptures with Tenolig: Quantitative analysis of postural control and gait pattern. The Foot. 2012;22(4):303-309.

42. Raleigh SM, Collins M. Gene Variants that Predispose to Achilles Tendon Injuries: An Update on Recent Advances. Achilles Tendon, A Čretnik, (Ed.), Creative Commons by 3.0 license. 2012;p.25-40. 